University of Chicago Law School

Chicago Unbound

Journal Articles

Faculty Scholarship

2009

\title{
Is the Bankruptcy Code an Adequate Mechanism for Resolving the Distress of Systemically Important Institutions?
}

Edward Morrison

Follow this and additional works at: https://chicagounbound.uchicago.edu/journal_articles

Part of the Law Commons

\section{Recommended Citation}

Edward Morrison, "Is the Bankruptcy Code an Adequate Mechanism for Resolving the Distress of Systemically Important Institutions?," 82 Temple Law Review 449 (2009).

This Article is brought to you for free and open access by the Faculty Scholarship at Chicago Unbound. It has been accepted for inclusion in Journal Articles by an authorized administrator of Chicago Unbound. For more information, please contact unbound@law.uchicago.edu. 


\title{
IS THE BANKRUPTCY CODE AN ADEQUATE MECHANISM FOR RESOLVING THE DISTRESS OF SYSTEMICALLY IMPORTANT INSTITUTIONS?
}

\author{
Edward R. Morrison
}

\section{INTRODUCTION}

The President ${ }^{1}$ and members of Congress ${ }^{2}$ are considering proposals that would give the government broad authority to rescue financial institutions whose failure might threaten market stability. These systemically important institutions include bank and insurance holding companies, investment banks, and other "large, highly leveraged, and interconnected" entities that are not currently subject to federal resolution authority. ${ }^{3}$ Interest in these proposals stems from the credit crisis, particularly the bankruptcy of Lehman Brothers. That bankruptcy, according to some observers, ${ }^{4}$ caused massive destabilization in credit markets for two reasons. First, market participants were surprised that the government would permit a massive market player to undergo a costly Chapter 11 proceeding. A very different policy had been applied to other systemically important institutions such as Bear Stearns, Fannie Mae, and Freddie Mac. Second, the bankruptcy filing triggered fire sales of Lehman assets. Fire sales were harmful to other non-distressed institutions that held similar assets, which suddenly plummeted in value. They were also harmful to any institution holding Lehman's commercial paper, which functioned as a store of value for entities such as

\footnotetext{
* Professor of Law, Columbia Law School. I thank Franklin Edwards, Jeffrey Gordon, Harold Novikoff, and participants at the 2009 Temple Law Review Symposium for very helpful comments and conversations. Nathan Rehn (Columbia JD 2009) provided excellent research assistance.

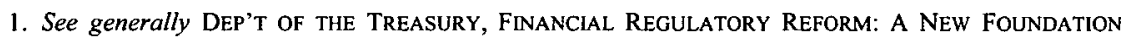
(2009), available at http://www.financialstability.gov/docs/regs/FinalReport_web.pdf [hereinafter FINANCIAL REGULATORY REFORM] (outlining Obama administration's proposed reforms that would give government more authority to regulate financial institutions through risk evaluation and monitoring); $c f$. DEP'T OF THE Treasury, Division D-Improvements for Financial Crisis Management, Title XII-Enhanced RESOLUTION AUTHORITY (proposed 2009), available at http:/www.financialstability.gov/docs/regulatory reform/title-XII_resolution-authority_072309.pdf [hereinafter DivisION D] (providing for emergency assistance from Department of Treasury to failing corporations).

2. Wall Street Reform and Consumer Protection Act of 2009, H.R. 4173, 111 th Cong., available at http://financialservices.house.gov/Key_Issues/Financial_Regulatory_Reform/FinancialRegulatoryReform/hr41 73eh.pdf; Restoring American Financial Stability Act of 2009, 11 lth Cong. (discussion draft), http://banking .senate.gov/public/_files/AYO09D44_xml.pdf.

3. FinanCial Regulatory ReForm, supra note 1, at 23.

4. E.g., Regulating and Resolving Institutions Considered "Too Big to Fail": Hearing Before the S. Comm. on Banking, Housing, \& Urban Affairs, 111 th Cong. 12-13 (2009) (statement of Sheila C. Bair, Chairman, Federal Deposit Insurance Corporation), http://banking.senate.gov/public/index.cfm?FuseAction= Files. View\&FileStore_id=4deb $17 \mathrm{aa}-\mathrm{b} 8 \mathrm{~b} 8-4 \mathrm{bc} 1-82 \mathrm{ef}-4 \mathrm{c} 57388 \mathrm{acf} 90$.
} 
the Primary Reserve Fund. ${ }^{5}$ Fire sales destroyed Lehman's ability to honor these claims.

Lehman's experience and the various bailouts (of AIG, Bear Stearns, and other distressed institutions) have produced two kinds of policy proposals. One calls for wholesale reform, including creation of a systemic risk regulator with authority to seize and stabilize systemically important institutions. Another is more modest and calls for targeted amendments to the Bankruptcy Code and greater government monitoring of market risks. ${ }^{6}$ This approach would retain bankruptcy as the principal mechanism for resolving distress at non-bank institutions, systemically important or not. ${ }^{7}$

Put differently, current debates hinge on one question: is the Bankruptcy Code an adequate mechanism for resolving the distress of systemically important institutions? One view says "no," and advances wholesale reform. Another view says "yes, with some adjustments." This Essay evaluates these competing views: Section II discusses the current structure of the Bankruptcy Code and its limited ability to protect markets from failing systemically important institutions. Section III outlines policy responses. In Section IV, I conclude that the Code is indeed inadequate for dealing with failures of systemically important institutions. A systemic risk regulator is needed because a judicially administered process cannot move with sufficient speed and expertise in response to rapidly changing economic conditions.

\section{THE CURRENT BANKRUPTCY-BASED APPROACH}

The Bankruptcy Code has, since its enactment, taken steps to mitigate systemic risk. ${ }^{8}$ This is the risk that one debtor's failure will infect other financial market participants, causing a chain reaction of insolvencies that destabilizes markets. The Code attempts to mitigate this risk through "safe harbors" for swaps, repos, and other financial contracts. When a debtor enters bankruptcy, non-debtor counterparties can terminate these contracts, exercise netting and setoff rights, and seize margin to the extent of the debtor's net obligations to the counterparties. ${ }^{9}$ These safe harbors allow

5. See, e.g., Christopher Condon, Reserve Primary Money Fund Falls Below \$1 a Share, BLOOMBERG.COM, Sept. 16, 2008, http:/www.bloomberg.com/apps/news?pid=20601087\&sid=a5O2ylgo 1GRU (reporting Reserve Primary Fund's historic loss resulting from Lehman's devalued commercial paper).

6. Consumer Protection and Regulatory Enhancement Act, H.R. 3310, 111th Cong. (2009), available at http:/www.govtrack.us/congress/billtext.xpd?bill=h111-3310; REPUBLICAN MEMBERS OF THE H. COMM. ON Fin. Servs., 111Th Cong., Financial Services Committee Republican Plan for Reforming the FINANCIAL REGULATORY SYSTEM (2009), http://republicans.financialservices.house.gov/images/stories/fscre pregreformplan.pdf.

7. See infra Sections II and III for a discussion of the current bankruptcy-based approach and other nonbankruptcy approaches.

8. See generally Franklin R. Edwards \& Edward R. Morrison, Derivatives and the Bankruptcy Code: Why the Special Treatment?, 22 YALE J. ON REG. 91 (2005) (discussing how exemptions afforded to financial contracts under the Bankruptcy Code are meant to prevent systemic risk); Edward R. Morrison \& Joerg Riegel, Financial Contracts and the New Bankruptcy Code: Insulating Markets from Bankrupt Debtors and Bankruptcy Judges, 13 AM. BANKR. INST. L. REV. 641 (2005) (same, but emphasizing 2005 reforms that expanded the exemptions).

9. Morrison \& Riegel, supra note 8, at 645 . 
counterparties to extricate themselves quickly from contracts with a failing debtor and thereby minimize their exposure to its distress. ${ }^{10}$

These provisions, however, are largely prophylactic: they aim to reduce the risk of systemic failure, not to manage a clear and present danger of a market meltdown. That danger exists when a major institution collapses. With or without the Code's safe harbors, the institution's failure will destabilize markets. Its failure infects financial markets through three channels. First, and most obviously, the institution will suspend payments on commercial paper and other debt instruments. This can have profound effects on financial markets because, when an institution is very large, its debt instruments are widely held. This was true of Lehman Brothers. After its failure, we saw important funds "break the buck," producing losses for investors or fund sponsors." Additionally, major market players may have sold credit default swaps ("CDS") to holders of a failing institution's debt. ${ }^{12}$ As the institution fails, payments under these CDS could destabilize the protection sellers, assuming they have not fully hedged their positions.

Second, the Code's safe harbors permit premature liquidation of failing institutions. ${ }^{13}$ Non-debtor counterparties rush to terminate existing contracts, dismembering the failing institution and preventing an orderly wind-down that might yield greater overall value to counterparties. As these counterparties suffer significant losses, they too may encounter financial distress. When Lehman Brothers entered bankruptcy in September 2008, it was party to about 1.5 million transactions with over 8,000 counterparties. ${ }^{14}$ Within two weeks, eighty percent of those transactions had been terminated, netted, and liquidated. ${ }^{15}$ Significant value was lost, some critics allege, because no party-Lehman, a trustee, or a judge-could implement an orderly winddown process. ${ }^{16}$

10. Id. at 642; Edwards \& Morrison, supra note 8, at 97-98.

11. These funds include the Reserve Primary Fund (the oldest money market fund) and BNY Mellon Institutional Cash Reserves (a securities lending fund). See Condon, supra note 5 (reporting that Reserve Primary Fund dropped below one dollar per share); Matthew Keenan \& Christopher Condon, BNY Mellon, Reserve Primary Rattle Fund Investors, BLOOMBERG.COM, Sept. 18, 2008, http://www.bloomberg.com/apps/ news?pid=20601087\&sid=aLCm3FmG9zX4 (reporting that BNY Mellon's Institutional Cash Reserves fell below one dollar per share).

12. See Serena Ng et al., Lehman Swap Payments Look Bigger than Expected, WALL ST. J., Oct. 11, 2008 , at B2 (reporting $\$ 400$ billion in credit-default swaps made on Lehman Brother's debt after it filed for bankruptcy).

13. Edwards \& Morrison, supra note 8 , at $94,101$.

14. Linda Sandler, Lehman Liquidation Cost May Swell $\$ 200$ Million as 480 Are Hired, BLOOMBERG.COM, Oct. 30, 2008, http://www.bloomberg.com/apps/news?pid=20601087\&sid=aUWNysWfY ZIY\&refer=home.

15. Jeffrey McCracken, Lehman's Chaotic Bankruptcy Filing Destroyed Billions in Value, WALL ST. J., Dec. 29, 2008, at A10; see also Video: Harvey Miller Speaking at Columbia Law School's Sixth Annual Deals Roundtable (Columbia Law School 2008), http://www.law.columbia.edu/media_inquiries/news_events/2008/ November2008/deals_round (discussing huge losses resulting from bankruptcy laws' lack of protection for financial institutions and their clients).

16. E.g., McCracken, supra note 15 (reporting that Lehman Brother's internal analysts estimated as much as $\$ 75$ billion of Lehman's value destroyed by chaotic bankruptcy filing). Also, the close-outs occurred in a market that was weakened as a result of Lehman's failure and had huge price swings in CDS for names like GMAC, AIG, Morgan Stanley, and Goldman Sachs. See, e.g., Morgan Stanley's CDS Lead Credit 
Third, and perhaps most important, rushed liquidation of a failed institution will be accompanied by large-scale efforts to sell off margin and rehedge positions by nondebtor counterparties. ${ }^{17}$ A counterparty will enter financial contracts with a financial institution in order to hedge other risky investments on the counterparty's balance sheet. The financial contract will often be collateralized: the parties will periodically pledge liquid securities ("margin") to collateralize their expected obligations to each other. When an institution fails, counterparties will net their outstanding contracts with the institution and seize margin to the extent that the institution is a net obligor. As margin is sold en masse, the price of the underlying collateral falls. Because the underlying collateral is typically composed of liquid securities that function as collateral for many market players, these players will see their assets decline in value. Additionally, as counterparties attempt to rehedge simultaneously, the price of hedging will rise precipitously, creating additional losses for the counterparties. Fear of these effects prompted the Federal Reserve to orchestrate a bailout of Long Term Capital Management ("LTCM") in fall $1998 .{ }^{18}$ Some critics believe that Lehman's bankruptcy similarly contributed to the subsequent freezing of credit markets. ${ }^{19}$

The failure of a systemically important institution will, therefore, destabilize markets regardless of whether the Bankruptcy Code offers safe harbors for financial contracts. Indeed, these safe harbors may exacerbate the instability by permitting a counterparty "run" on the failing institution.

The government's response, thus far, has been to bail out institutions before they fail (AIG, Bear Stearns) or perform triage afterward (Lehman). ${ }^{20}$ The government's ability to respond has, according to some officials, been hamstrung by legal constraints. Indeed, one view of Lehman's bankruptcy is that the government was powerless to prevent it. The Federal Reserve can make loans, as it did to Bear Stearns and AIG, if the borrower posts sufficient collateral. ${ }^{21}$ Lehman, however, was highly insolvent and lacked adequate collateral, according to government officials, ${ }^{22}$ which rendered it

Spreads Wider, REUTERS, Oct. 10, 2008, http://www.reuters.com/article/rbssFinancialServicesAndRealEstate News/idUSN 1036473720081010 (reporting that credit markets weakened in anticipation of credit-default swaps on Lehman's debt, affecting firms such as Morgan Stanley).

17. See Edwards \& Morrison, supra note 8, at 99-106 (recounting circumstances surrounding rushed liquidation of LTCM).

18. Id. at 100 .

19. See, e.g., Carrick Mollenkamp et al., Lehman's Demise Triggered Cash Crunch Around Globe; Decision to Let Firm Fail Marked a Turning Point in Crisis. WALL. ST. J., Sept. 29, 2008, at Al (reporting that Lehman Brother's collapse sent credit markets into disarray).

20. See, e.g., Ben S. Bernanke, Chairman, Fed. Reserve Sys., Speech at the Greater Austin Chamber of Commerce: Federal Reserve Policies in the Financial Crisis (Dec. 1, 2008), http://www.federalreserve.gov/ newsevents/speech/bernanke20081201a.htm (discussing Federal Reserve strategy for dealing with financial crisis, including policy for helping failing institutions); Michael D. Bordo, An Historical Perspective on the Crisis of 2007-2008, at 3-4 (Nat'l Bureau of Econ. Research, Working Paper No. 14569, 2008), available at http://www.nber.org/papers/w14569.pdf (discussing Federal Reserve's decisions to bail out Bear Stearns and allow Lehman Brothers to fail).

21. David Small \& James Clouse, The Limits the Federal Reserve Act Places on the Monetary Policy Actions of the Federal Reserve, 19 ANN. REV. BANKING L. 553, 560-65 (2000).

22. See, e.g., Confirmation of Mr. Timothy F. Geithner to Be Secretary of the U.S. Department of Treasury, 111 th Cong. 82-83 (2009) (statement of Timothy Geithner, Treasury Secretary Nominee, answering questions from Sen. Snowe) (explaining government's attempt to avoid Lehman's default once it was evident 
ineligible for assistance. This account has been questioned, ${ }^{23}$ but has helped fuel proposals that would give the government broad authority to address the limits of bankruptcy law.

\section{NON-BANKRUPTCY OPTIONS}

Congress and regulators are now considering two options: enact insolvency legislation for non-bank institutions or modify Chapter 11 to accommodate these institutions. The former is favored by President Obama; ${ }^{24}$ the latter by Republicans in the House of Representatives. ${ }^{25}$

\section{A. Insolvency Legislation for Non-Banks}

Under this approach, the federal government would have power to seize systemically important institutions and dictate their futures-reorganization, sale, or liquidation-in order to minimize effects on financial markets and costs to taxpayers. ${ }^{26}$ These institutions might be barred from filing a bankruptcy petition, or the government might be given the right to intervene in a bankruptcy case, stripping the court of jurisdiction. $^{27}$

To be effective, this approach to systemic risk should have three elements: (i) a clear definition of "systemically important institutions," (ii) transparent procedures for rescuing these institutions, and (iii) a broad regulatory framework that guides the relevant federal agency and the financial institutions before the institutions hemorrhage.

\section{Definitions}

A "systemically important institution" would likely be one that (i) falls within a category of institutions that have an important presence in financial markets and (ii) whose failure would threaten market stability. Category (i) almost surely includes any institution subject to prudential regulation, including investment banks, money market funds, and mutual funds. Although hedge funds currently sit outside the scope of most

that firm could not fund itself); Joe Nocera \& Edmund L. Andrews, Running a Step Behind as a Crisis Raged, N.Y. Times, Oct. 23, 2008, at Al (reporting that Federal Reserve could not bail out Lehman because it did not have enough assets to serve as collateral); Bernanke, supra note 20 (arguing that Lehman's failure was unavoidable, given firm's lack of collateral and legal restraints upon Federal Reserve).

23. See, e.g., Editorial, Questions for Mr. Geithner, N.Y. TimEs, Dec. 15, 2008, at A34 (arguing that Federal Reserve had insufficient information when deciding to let Lehman fail).

24. See generally FINANCIAL REgULATORY REFORM, supra note 1 (outlining Obama administration's proposed reforms, including legislation aimed at failing non-bank financial institutions).

25. See supra note 6 for sources explaining Republican position on regulatory reform.

26. FinANCIAL REgUlatoRY REFORM, supra note 1, at 76-79.

27. A similar right of intervention is possessed by the Securities Investor Protection Corporation (SIPC) in stockbroker liquidations under Chapter 7. See generally 11 U.S.C. $\$ 742$ (2006); Daniel J. Morse, When a Securities Brokerage Firm Goes Broke: A Primer on the Securities Investment Protection Act of 1970, 25 AM. BANKR. INST. J. 34 (2006). 
regulations-a situation that will likely change in the near future ${ }^{28}$ - the LTCM bailout suggests that they too form a class of institutions that is systemically important.

An institution falls within category (ii) if it is sufficiently large, leveraged, complex, and capitalized by illiquid assets that its failure would destabilize markets. ${ }^{29}$ Even if an institution does not achieve a massive scale, it can still be systemically important if it is behaving similarly to a large number of institutions that are systemic as part of a "herd." 30

Legislation could establish the types of institutions within category (i). Category (ii) requires judgment from a regulator, who must decide whether an institution's scale or comovement with other firms renders it systemically important. That judgment could be given to the relevant regulator for the industry, or it could be given to a single decision maker such as the Federal Reserve. If discretion is given to industry regulators, the benefits are industry-specific expertise and regulatory competition; the costs are regulatory capture and politically charged exercise of discretion. If discretion is given to a single regulator, the benefits are greater (but still incomplete) political insulation and centralized decision making; the cost is a lack of industry-specific expertise. ${ }^{31}$ These are theoretical cost-benefit tradeoffs; in practice, the comparison is very muddy, leaving no obvious basis for preferring a single regulator over multiple regulators.

\section{Rescue Procedures}

The relevant agency must be given fairly broad power to wind down, reorganize, or sell off a distressed institution. Commercial banking law provides a useful template. The Federal Deposit Insurance Corporation ("FDIC" or "the Corporation") has authority to seize control of a commercial bank that is approaching (or has entered) insolvency ${ }^{32}$ or has engaged in conduct signaling fraud or unsound risk management

28. See, e.g., Financial Regulatory Reform, supra note 1, at 37-38 (proposing that hedge funds be required to register with SEC and Commodity Futures Trading Commission).

29. Along these lines, the Treasury has proposed three factors that may help identify systemically important institutions:

- the impact the firm's failure would have on the financial system and the economy;

- the firm's combination of size, leverage (including off-balance sheet exposures), and degree of reliance on short-term funding; and

- the firm's criticality as a source of credit for households, businesses, and state and local governments and as a source of liquidity for the financial system.

Id.

30. Markus Brinnermeier et al., The Fundamental Principles of Financial Regulation 25-26 (Int'l Ctr. for Monetary \& Banking Studies 2009).

31. See Perspectives on Regulation of Systemic Risk in the Financial Services Industry: Hearing Before the H. Comm. on Financial Servs., 111 th Cong. app. at 163-67 (2009) (testimony of Peter J. Wallison, Arthur F. Burns Fellow in Financial Policy Studies, American Enterprise Institute), for a discussion on the costs of centralized decision making.

32. Intervention is necessary, for example, when a bank is "critically undercapitalized," defined as equity capital representing two percent or less of total assets. 12 U.S.C. $\S 1831 \mathrm{lo}(\mathrm{b})(1)(\mathrm{E})$, (c)(3) (2006). If an institution becomes critically undercapitalized, the FDIC is required to restrict its activities in statutorily prescribed ways. $I d$. $\S 1831 \mathrm{o}(\mathrm{i})$. The FDIC may appoint a receiver at any time within 90 days. $/ d$. $\S 1831 \mathrm{o}(\mathrm{h})$. This rule prevents federal regulators from gambling on bank resurrection. 
practices. ${ }^{33}$ Once it intervenes, the FDIC has broad power to succeed to the institution, operate it, revoke its charter, remove management, and choose whether to liquidate the bank or reorganize it. ${ }^{34}$ The FDIC's decisions are not subject to court oversight or notice and hearing requirements. ${ }^{35}$ The FDIC's mandate is to resolve bank insolvencies in ways that achieve the lowest cost to federal deposit insurance funds. ${ }^{36}$

Five broad strategies are available:

(1) Purchase and Assumption. The FDIC may transfer the failing bank to a solvent institution. ${ }^{37}$ This is a rapidly executed strategy: a bank may be seized on Friday and its balance sheet transferred to a solvent bank before the opening of business on Monday. ${ }^{38}$ To make the transaction attractive to the acquiring bank, the FDIC may agree to share losses from risky assets or compensate the acquirer if transferred liabilities exceed the value of assets. ${ }^{39}$ Of course, this payment often functions as full insurance for creditors of the failed bank; they may suffer no haircut as a result of the bank's failure.$^{40}$ Critics therefore argue that "purchase and assumption" transactions can generate excessive costs (borne by the federal deposit insurance funds) as well as moral hazard (because creditors are insensitive to a bank's riskiness). ${ }^{41}$ Strategies analogous to "purchase and assumption" were applied to Bear Stearns and WaMu, both sold to JPMorgan. ${ }^{42}$ In the first case, however, the sale was orchestrated by the Federal Reserve, not the FDIC.

(2) Bridge Banks and New Banks. The FDIC may capitalize a new bank that assumes the balance sheet of a failed institution..$^{43}$ The new bank may be a temporary measure (a "bridge bank") that exists only while the FDIC identifies the best resolution of the failed bank's operations, a process that can take up to two years. Or the new bank may be a permanent institution-a new bank-whose stock the FDIC will eventually sell to investors (the stock can be sold to private investors, such as private

33. Id. $\S 1821(\mathrm{c})(5)$.

34. Id. $\S 191$ (a). See generally JONATHAN R. MACEY ET AL., BANKING LAW AND REGULATION ch. 10 (3d ed. 2001) (discussing FDIC's broad authority once it intervenes to rescue failing or threatened bank).

35. James Madison Ltd. v. Ludwig, 82 F.3d 1085, 1092-93 (D.C. Cir. 1996). Judicial review is available for the decision to impose a receivership or conservatorship, but not for subsequent decisions by the federal agency. $I$. .

36. 12 U.S.C. $\$ 1823(\mathrm{c})(4)$.

37. Id. $\S 1821(\mathrm{~d})(2)(\mathrm{G}), 1823(\mathrm{c})(2)(\mathrm{A})(\mathrm{iii})$.

38. For a useful, oft-quoted, but somewhat outdated summary of the process, see Gunter v. Hutcheson, 674 F.2d 862, 865-66 (11 th Cir. 1982).

39. 12 U.S.C. § 1823(c)(2), (c)(4); see also FED. DEPOSIT INS. CORP., RESOLUTIONS HANDBOOK 29-35 (2003), available at http://www.fdic.gov/bank/historical/reshandbook/ (describing FDIC's use of loss purchase and assumption transactions to transfer assets of failed banks to solvent banks).

40. FED. DEPOSIT INS. CORP., supra note 39, at 29.

41. See FED. DEPOSIT INS. CORP., supra note 39, at 20-21, for a summary of these critiques.

42. See generally Fed. Deposit InS. Corp. \& JPMorgan Chase BanK, Purchase and Assumption AGREEMENT: WHOLE BANK (2008), available at http://www.fdic.gov/about/freedom/Washington_Mutual_P_ and_A.pdf; Robin Sidel et al., J.P. Morgan Buys Bear in Fire Sale, as Fed Widens Credit to Avert Crisis, WALL ST. J., Mar. 17, 2008, at Al; Robin Sidel et al., WaMu Is Seized, Sold Off to J.P. Morgan, in Largest Failure in U.S. Banking History, WALL ST. J., Sept. 26, 2008, at Al; Andrew Ross Sorkin \& Landon Thomas Jr., JPMorgan Acts to Buy Ailing Bear Stearns at Huge Discount, N.Y. Times, Mar. 16, 2008, at A1.

43. 12 U.S.C. $\S 1821(\mathrm{~m})$, (n). See generally FED. DEPOSIT INS. CORP., supra note 39, at 35-40. 
equity firms). ${ }^{44}$ In either case, the FDIC can transfer all or part of a failed institution's balance sheet. ${ }^{45}$ Creditors cannot object but are entitled to recoveries at least as large as they would receive in a liquidation ${ }^{46}$ Last year, the FDIC chartered a bridge bank to salvage the operations of Silverton Bank. ${ }^{47}$

(3) Receivership and Liquidation. The FDIC can assume the role of receiver, marshal and liquidate bank assets, pay depositors or transfer their accounts to another institution, and then distribute the remaining value in the estate to other claimants. ${ }^{48}$ The procedure is typically used when no healthy institution is willing to acquire the failing bank's balance sheet. ${ }^{49}$ Critics argue that a version of receivership and liquidation should have been applied to Lehman to ensure an orderly wind-down. ${ }^{50}$

(4) Conservatorship and Government Assistance. The federal government has authority to appoint itself as conservator of a bank-without revoking its charter-and operate it with a view toward rehabilitation. ${ }^{51}$ Until recently, the FDIC rarely employed this strategy. ${ }^{52}$ In mid-2008, the Corporation was designated conservator for IndyMac, a federal savings bank. ${ }^{53}$ About two months later, another federal agency-the Federal Housing Finance Agency ("FHFA")-became conservator for the governmentsponsored entities ("GSEs") Fannie Mae and Freddie Mac. ${ }^{54}$ The Housing and Economic Recovery Act of $2008^{55}$ created the FHFA to regulate the GSEs. ${ }^{56}$ The

44. 12 U.S.C. $§ 1821(\mathrm{~d})(2)(\mathrm{F}),(\mathrm{m})$. If an initial public offering ("IPO") of the bank's stock fails, the FDIC must arrange a purchase and assumption transaction or liquidate the new bank within two to five years of its origination. $I d$. $\S 1821(\mathrm{~m})(17)$. New banks must be wound up within two years, but the FDIC has discretion to extend the life of a bridge bank for three additional one-year periods. Id. $\S 1821(\mathrm{n})(9)$

45. Id. $\S 1821$ (c)(5); FED. DEPOSIT INS. CORP., supra note 39, at 37.

46. 12 U.S.C. $\S 1821(\mathrm{~d})(2)(\mathrm{G})(\mathrm{i})(\mathrm{II}),(\mathrm{i})(2)$.

47. Press Release, Fed. Deposit Ins. Corp., FDIC Creates Bridge Bank to Take Over Operations of Silverton Bank, National Association, Atlanta, Georgia (May 1, 2009), available at http:/www.fdic.gov/news /news/press/2009/pr09061.html

48. See generally FED. DEPOSIT INS. CORP., supra note 39, at 41-46.

49. Id. at 41 .

50. The "disorderly failure" of Lehman was, in part, the motivation for President Obama's proposal for "the creation of a resolution regime to allow for the orderly resolution of failing" institutions "in situations where the stability of the financial system is at risk." FINANCIAL REGULATORY REFORM, supra note 1, at 76; see also Regulating and Resolving Institutions Considered "Too Big to Fail," supra note 4 (advocating new regulatory approach for important financial institutions). See generally Nouriel Roubini, Op-Ed., We Need a New Insolvency Regime for Banks, FORBES.COM, Mar. 26, 2009, http://www.forbes.com/2009/03/25/banksnationalization-fdic-bankruptcy-opinions-columnists-insolvency-roubini.html.

51. 12 U.S.C. $\S 1821(\mathrm{~d})(2)(\mathrm{D})$.

52. FED. DEPOSIT INS. CORP., supra note 39, at 69 n.2 ("[T]he FDIC has never been appointed conservator by the OCC or a state regulatory authority and may decline the appointment if tendered; the FDIC was appointed conservator once by the Office of Thrift Supervision [in the case of IndyMac].").

53. See generally Damian Paletta et al., IndyMac Reopens, Halts Foreclosures on Its Loans, WALL ST. J., July 15, 2008, at C1; Federal Deposit Insurance Corporation, Failed Bank Information: Information for IndyMac Bank, F.S.B., and IndyMac Federal Bank, F.S.B., Pasadena, CA, http://www.fdic.gov/bank/indivi dual/failed/IndyMac.html (last visited Nov. 19, 2009).

54. MARK Jickling, CRS Report for CONGress: FANNIE MAE AND Freddie MAC IN CONSERVATORSHIP 2-4 (2008), available at http://fpc.state.gov/documents/organization/1 10097.pdf.

55. Housing and Economic Recovery Act of 2008, Pub. L. No. 110-289, 122 Stat. 2654 (codified as amended in scattered sections of 12 U.S.C.).

56. 12 U.S.C. $\S 4511$. 
statute grants the FHFA authority to appoint a conservator after determining that a GSE is critically undercapitalized. ${ }^{57}$ Pursuant to this authority, the FHFA appointed itself conservator of Fannie Mae and Freddie Mac on September 7, 2008. ${ }^{58}$ Having arrogated all powers possessed by shareholders, directors, and officers, it implemented a plan under which the Treasury Department will provide up to $\$ 100$ billion in financing in exchange for warrants to purchase up to $79.9 \%$ of the GSE's common stock (at a price of $\$ 0.00001$ per share).$^{59}$ The Housing and Economic Recovery Act places no limit on the length of the conservatorship..$^{60}$

(5) Open Bank Assistance. The FDIC can inject liquidity into troubled banks if the transfer will prevent a likely receivership or conservatorship, the transfer will prevent the bank from breaching capital reserve requirements, and the bank's managers are competent and have not violated any laws or regulations. ${ }^{61}$ This strategy is, of course, controversial because it protects both creditors and shareholders from the bank's financial distress. ${ }^{62} \mathrm{~A}$ version of open bank assistance was applied to AIG, with the Federal Reserve injecting $\$ 85$ billion in return for equity participation notes. ${ }^{63}$

Strategies along these lines could be among the powers available to a systemic risk regulator. Instead of minimizing the cost to federal deposit insurance funds, which is the goal of the FDIC, ${ }^{64}$ the regulator would minimize the cost to creditors, financial markets, and the public from the failure of a systemically important institution. Affected parties might have a right of appeal, but the regulator would have discretion to select the appropriate strategy without prior court approval.

\section{Regulatory Framework}

Rescue legislation cannot exist in isolation. Because it vests the federal government-the Treasury, the Fed, or an agency-with enormous discretion, the legislation must be tied to a broad regulatory framework that limits government discretion and gives clear guidance to institutions that are subject to potential takeover.

Again, commercial banking law provides a useful analogue. Long before it fails, a bank is subject to ongoing, prudential regulation by state or federal regulators. ${ }^{65}$ This

57. Id. $\S 4617$.

58. See Press Release, Henry M. Paulson, Jr., Sec'y of the Treasury, Statement on Treasury and Federal Housing Finance Agency Action to Protect Financial Markets and Taxpayers (Sept. 7, 2008), available at http:/www.treas.gov/press/releases/hpl129.htm (announcing and detailing reasons for FHFA's conservatorship of Fannie Mae and Freddie Mac).

59. JiCKLING, supra note 54 , at 3.

60. 12 U.S.C. $\S 4617$; see also Federal Housing Finance Agency, Fact Sheet: Questions and Answers on Conservatorship, http://www.treas.gov/press/releases/reports/fhfa_consrv_faq_090708hpl 128.pdf (last visited Nov. 19, 2009).

61. 12 U.S.C. $\S 1823(\mathrm{c})(8)$.

62. FED. DEPOSIT INS. CORP., supra note 39, at 47.

63. Matthew Karnitschnig et al., U.S. to Take Over AIG in \$85 Billion Bailout; Central Banks Inject Cash as Credit Dries Up, WALL ST. J., Sept. 17, 2008, at A1.

64. See 12 U.S.C. $\S 1823(\mathrm{c})(4)$ (providing that FDIC may exercise authority only at least possible cost to federal deposit insurance funds, and prescribing methods of determining least costly approach).

65. See generally MACEY ET AL., supra note 34, at 70-73. 
regulation includes capital reserve requirements, ${ }^{66}$ limits on lending ${ }^{67}$ and other investment activities, ${ }^{68}$ and periodic reports ${ }^{69}$ and audits. ${ }^{70}$ The relevant state or federal regulator is charged with the responsibility for initiating any conservatorship or receivership. ${ }^{71}$ Similarly, the GSEs and Federal Home Loan Banks are subject to regulations governing their capitalization and business practices, and their regulator, the FHFA, is the decision maker with respect to initiation of any conservatorship or receivership proceedings. ${ }^{72}$

Prudential regulation serves three critical functions. First, it reduces the moral hazard caused by deposit insurance or any other form of government insurance. ${ }^{73}$ Insurance dulls the incentives of the insured parties-the bank and its creditors or depositors - to monitor and, if necessary, reduce the riskiness of the bank's activities. ${ }^{74}$ This moral hazard problem necessitates vigorous monitoring by the insurer ${ }^{75} \mathrm{We}$ see this in the detailed reporting and auditing requirements of bank regulations. ${ }^{76}$ Second, prudential regulation ensures that both the regulator and the public receive timely information about a commercial bank's condition long before distress occurs. ${ }^{77}$ When the FDIC does intervene to rescue a bank, there will be a long paper trail that justifies the intervention. Finally, prudential regulation cabins FDIC discretion by establishing objective, often quantifiable, standards for determining whether conservatorship or receivership is justified. ${ }^{78}$

Laws governing failing banks, then, have always been tied to a framework regulating healthy banks. Without a similar framework, rescue legislation would be deeply troubling because it would give the government wide-ranging, politically

66. See 12 U.S.C. $\$ 1818(\mathrm{a})(8)(\mathrm{A})$ (empowering FDIC to suspend deposit insurance for institutions without tangible capital).

67. See id. § 84(a) (prescribing formulas to tie lending limits to collateral).

68. See id. $\$ 24$ (restricting equity investments in corporations).

69. See id. $\S 161$ (requiring institutions to provide reports to Comptroller of Currency regarding condition of institution and payment of dividends).

70. See id. $\S 1820$ (d) (mandating annual on-site examinations for all insured institutions).

71. See generally MACEY ET AL., supra note 34, at 725-26 (discussing process of appointing fiduciary to manage bank's affairs).

72. 12 U.S.C. $\S \S 4511-4519$; see also Federal Housing Finance Agency, About FHFA, http://www.fhfa. gov/Default.aspx?Page $=4$ (last visited Oct. 21, 2009) (outlining FHFA's functioning). See supra text accompanying notes 54-60 for a discussion of the FHFA's establishment and operation.

73. See STUART I. GREENBAUM \& ANJAN V. THAKOR, CONTEMPORARY FINANCIAL INTERMEDIATION 443 (2d ed. 2007) (positing that public regulation is necessary to reduce moral hazard).

74. See id. (noting that deposit insurance and other government safeguards intended to protect private banks ultimately move costs and risks from banks to public and disincentivize banks' self-regulation).

75. See id. at 445 (analogizing moral hazard problem in fire insurance policies to banking industry).

76. See supra notes 65-72 and accompanying text for a discussion of bank regulation requirements.

77. Inadequate information may have contributed to the curtent crisis. See RICHARD A. POSNER, A FAILURE OF CAPITALISM: THE CRISIS OF '08 AND THE DESCENT INTO DEPRESSION 145-46 (2009) (stating that housing bubble started to deflate in 2005 , but government did not discover problem in banking industry until fall 2008).

78. See, e.g., Robert R. Bliss \& George G. Kaufman, U.S. Corporate and Bank Insolvency Regimes: A Comparison and Evaluation, 2 VA. L. \& BUS. REV. 143, 152 (2007) (noting that statutory minimum capital reserve requirements are designed in part to "reduce[ the discretion of bank regulators to decide when to appoint receivers"). 
sensitive discretion in selecting "distressed" institutions for a federal takeover. In the absence of rules guiding the behavior of regulators and financial institutions, government decisions will be biased by political pressure. For example, fear of adverse political or public reaction could delay a much-needed rescue. A timely rescue will often be one that occurs when an institution has not yet defaulted or entered distress. The rescue may seem premature to outsiders, even if the agency believes that the company is in danger of default. ${ }^{79}$ And there will indeed be a real risk of premature rescue. Because reasonable minds can disagree whether an institution is "in danger of default," politics can enter the decision-making process (consciously or subconsciously). ${ }^{80}$

Additionally, without a regulatory framework, the relevant federal agency might have insufficient information to make timely rescue decisions. And, as noted before, rescue legislation could even increase systemic risk, because it would dampen the monitoring incentives of creditors, investors, and other private actors. ${ }^{81}$ Prudential regulation is needed to address this moral hazard problem.

To be sure, prudential regulation will not eliminate concerns about regulators abusing their discretion. Even though the FDIC and FHFA operate within a comprehensive regulatory framework, their rescue decisions are not immune to criticism. ${ }^{82}$ But the goal of legislation is not to remove discretion from federal actorsthat is impossible. The goal is to constrain it in ways that limit ill-informed or biased decisions. That is possible, but only through legislation that channels the decision making of systemically important institutions as well as the government actors empowered to rescue them.

\section{B. Modifying Chapter 11}

The rescue powers of the FDIC-receivership, conservatorship, purchase and assumption, creation of a bridge bank, etc.--are similar to those of a judge in a Chapter 11 case. Once an institution files for bankruptcy, it enjoys insulation from creditors (the "automatic stay"). ${ }^{83}$ The bankruptcy judge can then approve gradual liquidation (akin to a receivership), ${ }^{84}$ reorganization (conservatorship), ${ }^{85}$ or sale of all or part of the

79. See POSNER, supra note 77, at 134-39 (discussing why warning signs were largely ignored and highlighting difficulty in pacifying public when attempting to prevent "unlikely" events from happening).

80. The response to the current financial crisis has been widely criticized for inconsistency. See Steve Matthews \& Vivien Lou Chen, Hoenig Hits Treasury for Lack of 'Decisive' Action, Bloomberg.com, Mar. 6, 2009, http://www.bloomberg.com/apps/news?pid=newsarchive\&sid=aRFsoblx5kBw (reporting senior Federal Reserve official's criticism of Treasury's "ad-hoc approach" to bank crisis).

81. See Tyler Cowen, Why Creditors Should Suffer, Too, N.Y. Times, Apr. 5, 2009, at BU1 (emphasizing that new proposals effectively protect creditors of big financial firms from "their own lending and trading mistakes").

82. E.g., Francis X. Diebold \& David A. Skeel, Jr., Geithner Is Overreaching on Regulatory Power, WALL ST. J., Mar. 27, 2009, at A11 (stating that FDIC did not assume control of IndyMac until after it had clearly failed).

83. 11 U.S.C. $\$ 362(a)$ (2006).

84. A firm can file a bankruptcy petition under Chapter 7 liquidation, id. $\$ \S 701-784$, or Chapter 11 reorganization, $i d$. $\S \S 1101-1174$. Liquidation can be accomplished under either chapter. See generally Douglas G. Baird, The Elements of BANKRUPTCY ch. 1 (4th ed. 2006). Circuit City, for example, 
institution's assets, together with financing provided by the government or another lender (purchase and assumption). ${ }^{86}$

These features make bankruptcy a potentially attractive mechanism for rescuing distressed institutions, including systemically important ones. ${ }^{87}$ One obvious problem is the safe harbors for financial contracts, discussed in Section II. Financial contracts are the primary - often the only-assets of financial institutions, and the safe harbors permit a "run" on these assets.

One solution is to eliminate the safe harbors, at least when a systemically important institution files for bankruptcy. Some members of Congress, for example, advocate creation of a new chapter of the Bankruptcy Code for financial institutions. ${ }^{88}$ Presumably this chapter would closely resemble Chapter 11, but the automatic stay would apply to all financial contract counterparties in order "to prevent runs on troubled institutions, thereby helping to alleviate the panic that could strike the financial system if a large institution finds itself facing difficulties." ${ }^{\circ 9}$ Other details remain to be worked out. The debtor would probably be limited in its ability to "cherry pick" or otherwise use the benefit of hindsight to gamble at the expense of financial contract counterparties. The debtor might also be given strict deadlines for disaffirming contracts. In this way, bankruptcy judges would be given authority-with respect to financial contracts-similar to that possessed by the FDIC in commercial bank insolvencies. ${ }^{90}$

Even with these fixes, however, the Bankruptcy Code would remain a poor fit for systemically important institutions. By the time an institution becomes obviously distressed, and its managers finally consider a bankruptcy filing, counterparties will have commenced a "run" on its assets and confidence in the financial system will have deteriorated. It seems unlikely that troubled institutions will seek bankruptcy protection before they exhibit signs of distress. The incentive to "gamble for resurrection"- to

underwent liquidation in Chapter 11. See Miguel Bustillo, Retailer Circuit City to Liquidate-ConsumerElectronics Pioneer Closing; 34,000 Workers Will Lose Jobs, WALL ST. J., Jan. 17, 2009, at B1 (reporting that Circuit City liquidated after failing to reorganize under Chapter 11).

85. 11 U.S.C. $\S \S 1101-1174$.

86. Sales are often conducted in Chapter 11 using $\$ 363(\mathrm{~b})$, which permits sales of assets outside the ordinary course. See Kenneth M. Ayotte \& Edward R. Morrison, Creditor Control and Conflict in Chapter 11, 1 J. LEGAL ANALYSIS 511, 534-36 (2009), available at https:/ojs.hup.harvard.edu/index.php/jla/article /view/57/53 (documenting frequency of " 363 sales" in large corporate bankruptcy cases); Douglas G. Baird \& Robert K. Rasmussen, Chapter 11 at Twilight, 56 STAN. L. REv. 673, 691-93 (2003) (same). Chrysler and General Motors, for example, were recently sold as going concerns, with financing provided by the federal government. See generally Mark J. Roe \& David Skeel, Assessing the Chrysler Bankruptcy, 108 MiCH. L. REV. (forthcoming 2010), available at http://papers.ssm.com/sol3/papers.cfm?abstract_id=1426530; Edward R. Morrison, Chrysler, GM, and the Future of Chapter 11 (Columbia Law \& Econ. Research Paper No. 365, 2009), available at http://papers.ssrn.com/sol3/papers.cfm?abstract id $=1529734$.

87. See Kenneth Ayotte \& David A. Skeel, Jr., Bankruptcy or Bailouts?, 35 J. CORP. L. (forthcoming 2010), available at http:/papers.ssrn.com/sol3/papers.cfm?abstract_id=1362639 (discussing features of bankruptcy law intended to aid financial distress).

88. RePubliCAN MEMBers of THE H. COMm. ON Fin. ServS., supra note 6, at 3.

89. Id.

90. See 12 U.S.C. $\S 1821(e)(8)$ (2006) (outlining parameters for certain financial contracts). See generally Robert R. Bliss \& George G. Kaufman, A Comparison of U.S. Corporate and Bank Insolvency Resolution, ECON. PERSP., 2d Q. 2006, at 44. 
delay bankruptcy as long as possible-will be very strong, particularly because equity holders generally receive nothing and managers often lose their jobs after a bankruptcy filing.

To be sure, a distressed institution can be forced into banknuptcy via an involuntary petition. Under current law, only a group of creditors with unpaid, unsecured claims can file such a petition. ${ }^{91}$ That could be changed. Perhaps the federal government could be given broad authority to file involuntary petitions against systemically important institutions, regardless of whether it is a creditor. But this power would be as troubling as proposals for a systemic risk regulator. Would the government possess sufficient information and proper incentives to file an involuntary petition at the appropriate time against the appropriate institutions? A broad regulatory framework would be needed to ensure that this happens. Of course, a bankruptcy judge could dismiss a premature involuntary bankruptcy petition, but the filing itself conveys negative information to the market and undermines confidence in the systemically important institution. ${ }^{92}$

A second problem is that the bankruptcy process is managed by a judge. Though federal regulators are subject to political pressure, they possess expertise that is generally beyond the ken of judges. When a systemically important institution suffers distress, rapid decision making is necessary. Federal law permits this kind of speed when the FDIC seizes a bank.$^{93}$ Most of the Corporation's decisions, for example, are not subject to judicial review. Speed is less likely in a bankruptcy case because the judge must offer due process to objectors. ${ }^{94}$ Though the Lehman bankruptcy was handled very quickly - the North American operations were sold to Barclay's within a week $^{95}$-it seems overly optimistic to expect that every bankruptcy judge would act with the same dispatch as the judge did in the Lehman bankruptcy case. ${ }^{96}$

91. 11 U.S.C. $\$ 303$ (b) (2006).

92. See Carrick Mollenkamp et al., Lehman Files for Bankruptcy, Merrill Sold, AIG Seeks Cash, WALL ST. J., Sept. 16, 2008, available at http://online.wsj.com/article/SB122145492097035549.html (describing negative impact of Lehman's bankruptcy filing on stock market).

93. See supra Section III.A.2 for an analysis of the rescue procedures and strategies available to the FDIC.

94. See, e.g., 11 U.S.C. $\S 1109$ (b) ("A party in interest . . may raise and may appear and be heard on any issue in a case under this chapter."); FED. R. BANKR. P. 6004 (as amended by U.S. ORDER 09-16, Mar. 26, 2009) (requiring notice and hearing before courts approve motions to sell assets); S. Motor Co. v. CarterPritchett-Hodges, Inc. (In re MMH Auto. Group), 385 B.R. 347, 372 (Bankr. S.D. Fla. 2008) (stating that procedural expediency does not trump due process). See generally Eric S. Richards, Due Process Limitations on the Modification of Liens Through Bankruptcy Reorganization, 71 AM. BANKR. L. J. 43, 44-5I (1997).

95. Lehman Brothers Holdings, Inc., the parent company, filed its Chapter 11 petition on September 15 , 2008. Bankruptcy Judge Peck approved the sale of Lehman Brothers Inc., a subsidiary, to Barclays on September 19, 2008. Order Under 11 U.S.C. $\S \S 105(a), 363$, and 365 and Federal Rules of Bankruptcy Procedure 2002, 6004 and 6006 Authorizing and Approving (A) the Sale of Purchased Assets Free and Clear of Liens and Other Interests and (B) Assumption and Assignment of Executory Contracts and Unexpired Leases, Docket No. 258, In re Lehman Brothers Holdings, Inc., No. 08-13555, 2008 WL 4385989 (Bankr. S.D.N.Y. Sept. 19, 2008).

96. A third problem is the international scope of most, if not all, major financial institutions. Any rescue will require extensive coordination with foreign governments, something bankruptcy courts are not well equipped to handle. 
The deficiencies in the bankruptcy process can be overcome, provided the government is willing to pay enough. It can intervene before a bankruptcy occurs by bailing out the troubled institution (as in AIG and Bear Stearns). It can also intervene afterwards by offering financing tied to strict covenants that force a quick reorganization or liquidation (as in Chrysler and GM). ${ }^{97}$ These measures are costly, but the costs impose a salutary brake on overeager regulators, particularly because they face public scrutiny when they use public funds to bail out failing institutions.

Put differently, little in the current regime prevents the federal government from conducting quick rescues and pursuing other measures to mitigate a systemic collapse. ${ }^{98}$ The current regime is just more costly for taxpayers when systemically important institutions fail than one that permits immediate federal takeover. These costs must be weighed against the costs of a system that permits federal takeovers. That system requires a massive regulatory apparatus to constrain agency discretion..$^{99}$

\section{CONCLUSION}

Returning to the key question: Is the Bankruptcy Code an adequate mechanism for resolving the distress of systemically important institutions? No. The government needs a process with more flexibility and speed than what the Code offers. Although the government can avoid the Code's constraints by bailing out or extending loans to failing institutions, the cost to taxpayers is too large.

President Obama has proposed a plausible alternative to the Code. It would vest the Federal Reserve-working with the Secretary of the Treasury, FDIC, and other federal regulators-with authority to act as a systemic risk regulator that monitors, regulates, and rescues any foreign or domestic financial institution ${ }^{100}$ whose "material financial distress . . . could pose a threat to . . United States financial stability or the ... United States economy." 101 The proposed legislation combines close

97. See, e.g., Gen. Motors Corp., Current Report (Form 8-K), at 2 (May 28, 2009), available at http:/www.sec.gov/Archives/edgar/data/40730/000119312509119940/d8k.htm (describing $\S 363$ sale proposal); Roe \& Skeel, supra note 86, at 12-18 (describing and criticizing § 363 sale of Chrysler); Press Release, U.S. Dep't of the Treasury, Obama Administration Auto Restructuring Initiative Chrysler-Fiat Alliance (Apr. 30, 2009), http://www.treas.gov/press/releases/tg1 15.htm (delineating Obama administration's role in Chrysler's restructuring).

98. Almost nothing stops the government from acting to protect markets. Recall that, according to various government officials, the Fed was powerless to stop Lehman's failure, due to statutory constraints on its lending abilities. See supra notes 20-23 and accompanying text. If true, this suggests that we might want to expand the Fed's lending powers to include unsecured loans. With greater power, the Fed would be better poised to prevent a costly bankruptcy filing.

99. The current regime also imposes discipline on financial institutions, which cannot expect conservatorships or bailouts in the event of distress. They instead face, as Lehman did, the prospect of rapid liquidation in Chapter 11. This prospect induces troubled institutions (pressured by creditors) to contact federal regulators and share information before a meltdown.

100. See Dep'T OF THE TReasury, Title II-Consolidated Supervision and Regulation of LaRge, INTERCONNECTED FINANCIAL FIRMS 2-3 (proposed 2009), available at http:/www.financialstability.gov/docs /regulatoryreform/07222009/titleII.pdf [hereinafter TITLE II] (defining "financial company" in various contexts).

101. Id. at 3; see also DIVISION D, supra note 1, at 4-6 (proposing procedure for determining whether financial institution is systemic risk). 
monitoring of institutions before they enter distress ${ }^{102}$ and FDIC-style resolution procedures ${ }^{103}$ when the institution craters. Importantly, it gives the federal government authority to place institutions into conservatorship or receivership only when their distress imperils the overall economy. If an institution is "critically undercapitalized" but its distress does not threaten market stability, the institution will be forced into bankruptcy instead of receivership or conservatorship. ${ }^{104}$ President Obama's proposal, therefore, invokes alternatives to bankruptcy only when economic conditions necessitate them. Plus, these alternatives are invoked by the same regulators that monitor systemically important institutions long before they fail. These features render the President's plan a viable, targeted approach to protecting financial markets and the overall economy from a financial institution's failure.

Complicated issues remain, of course. If the FDIC does place an institution in receivership, some but not all assets and liabilities may be transferred to a stable purchaser or bridge bank. For example, an investment bank's financial contracts portfolio-but not its real estate, bonds, and commercial paper-might be transferred to a bridge bank. The government may believe that market stability is threatened by quick liquidation of the portfolio, but that quick liquidation of real estate or defaults on bonds and commercial paper create no systemic risk. In a case like this, how should the left-behind assets and liabilities-the "rump"-be handled? ${ }^{105}$ There will, for example, be complicated questions about the relative priority of creditors and whether prereceivership payments to creditors or equity holders should be clawed back. Should these questions be resolved by the FDIC, or should the rump be transferred to a bankruptcy court for administration? The bankruptcy court will apply well-established rules; FDIC decision making is more opaque. An investment bank's bonds and commercial paper may be easier to value-and therefore more liquid-if they are subject to transparent bankruptcy rules in the event of a receivership. Important issues such as these must be resolved before systemically important institutions are subject to a new resolution regime. But these issues are largely details and should not detract from the broader lesson of the financial crisis: the Bankruptcy Code is not an adequate mechanism for resolving the distress of systemically important institutions.

102. FINANCIAL REGULATORY REFORM, supra note 1 , at 20.

103. Id. at 76.

104. See TITLE II, supra note 100 , at 32 (describing obligatory bankruptcy for "critically undercapitalized Tier 1 financial holding companies").

105. This issue is discussed in Systemic Regulation, Prudential Matters, Resolution Authority and Securitization: Hearing Before the H. Comm. on Financial Servs., 111th Cong. 9-22 (2009) (statement of T. Timothy Ryan, Jr., President and CEO of the Securities Industry and Financial Markets Association), http://www.house.gov/apps/list/hearing/financialsvcs_dem/ryan___sifma.pdf. 
